\title{
ALIH PENGETAHUAN DAN TEKNOLOGI MELALUI KEGIATAN PENDAMPINGAN TENAGA KERJA ASING (STUDI KASUS DI YOGYAKARTA)
}

\section{KNOWLEDGE AND TECHNOLOGY TRANSFER ACTIVITY THROUGH LABOR FOREIGN ASSISTANCE (CASE STUDY IN YOGYAKARTA)}

\author{
Nurlia Rahmatika, Nur Siti Annazah \\ Pusat Penelitian dan Pengembangan, Kementerian Ketenagakerjaan RI \\ Jl. Jendral Gatot Subroto Kav. 51, Jakarta Selatan, DKI Jakarta \\ tiikaa.fad@gmail.com,anazah.siti@gmail.com
}

\begin{abstract}
ABSTRAK
Meskipun pemerintah telah mengatur pengendalian penggunaan TKA secara tegas dalam peraturan perundangundangan melalui kewajiban alih pengetahuan dan teknologi berbentuk kegiatan pendampingan bagi setiap TKA yang dipekerjakan, pada praktiknya hal tersebut tidak terselenggara dengan baik akibat timbulnya dinamika sosial, geografi, dan budaya antara TKA dan TK Pendamping di Perusahaan. Tujuan penelitian ini adalah mengevaluasi kegiatan pendampingan yang telah dilakukan dalam rangka alih pengetahuan dan teknologi di Yogyakarta. Metodelogi yang digunakan adalah studi kualitatif dengan mengumpulkan data melalui kuesioner, wawancara, dan FGD. Hasil penelitian menemukan bahwa masalah tidak berjalannya alih pengetahuan dan teknologi pada perusahaan pengguna TKA di Yogyakarta berawal dari tidak adanya pedoman baku mengenai teknis dan pelaksanaan kegiatan pendampingan TKA dari regulator, sehingga perusahaan mengalami kebingungan hingga menerapkan standar prosedur yang berbeda-beda meskipun dalam bidang usaha yang sama. Mulai dari mekanisme penunjukkan, efektivitas dan teknis pelaksanaan kegiatan pendampingan, monitoring dan evaluasi kegiatan pendampingan hingga metode ideal pelaksanaan kegiatan pendampingan.
\end{abstract}

Kata Kunci: Penggunaan TKA, Kegiatan Pendampingan TKA, Alih Pengetahuan dan Teknologi.

\begin{abstract}
While the government has strictly regulate the control of using foreign workers in the legislation of obligation to transfer knowledge and technology shaped understudied activity for every foreign employees, in practice it was not carried out properly due to the emergence of social, geographic, and cultural dynamics between foreign and local employees as understudies in the firm. The aim of this study is evaluate the understudies activities that have been implementing in order to knowledge and technology transfer in Yogyakarta. The methodology used a qualitative study by collecting data through questionnaires, interviews, and FGDs. The results of the study found that the problem of unsuccessfully transfer knowledge and technology in foreign employment firms in Yogyakarta has triggered by the absence of standard guidelines about the technical and implementation of understudied activity by the regulator, so the firm met confusion up to apply a different standard procedures even in the same business field. Starting from the selection mechanism, the effectiveness and technical implementation in the understudied activity, monitoring and evaluation of understudied activity up to the ideal method of implementing understudied activity.
\end{abstract}

Keywords: Using Foreign Workers, Understudies Activities for Foreign Worker, Knowledge and Technology Transfer.

\section{PENDAHULUAN}

Pemodal asing yang melakukan investasi ke Indonesia pada umumnya akan menggunakan tenaga kerja dari negaranya sendiri. Pasal 10 ayat (2) Undang-Undang Nomor 25 Tahun 2007 tentang Penanaman Modal menyebutkan perusahaan penanaman modal berhak menggunakan tenaga ahli warga Negara asing untuk jabatan dan keahlian tertentu sesuai dengan ketentuan peraturan perundangundangan. Namun, Pemerintah juga membatasi penggunaan TKA dengan syarat-syarat yang diatur dalam Undang-Undang Nomor 13 Tahun 
2003 tentang Ketenagakerjaan dalam Pasal 4249. Adapun pembatasan jabatan-jabatan yang dapat diisi oleh TKA diatur dalam pasal 5 ayat (1) Perpres No. 20 Tahun 2018 tentang penggunaan TKA dan dirinci dalam Kepmenaker No. 40 Tahun 2012 tentang jabatan-jabatan yang dilarang diduduki TKA dimana TKA yang boleh bekerja di Indonesia adalah tenaga ahli dan konsultan.

Penggunaan Tenaga Kerja Asing menjadi dilema yang sulit bagi pemerintah Indonesia. Di satu sisi merupakan salah satu konsekuensi yang tak terelakkan lagi dari adanya penyelenggaraan penanaman modal/investasi untuk menggerakkan dan meningkatkan pertumbuhan ekonomi nasional berkelanjutan, perluasan kesempatan kerja, meningkatkan kapasitas dan kemampuan teknologi nasional, serta tuntutan perkembangan perekonomian dunia yang ditandai oleh semakin ketatnya kompetisi antarbangsa dalam perdagangan pasar bebas. Keterlibatan Indonesia dalam berbagai kerja sama internasional baik secara bilateral, regional maupun multilateral (World Trade Organization/WTO) dalam perdagangan pasar bebas, menimbulkan berbagai konsekuensi yang harus dihadapi seperti membuka kesempatan masuknya TKA. Melarang masuknya TKA apalagi dalam kaitannya dengan intra agencies transfer yaitu pembeli perusahaan dibolehkan untuk membawa pimpinan dan atau tenaga ahli yang dibutuhkannya, akan membawa dampak ekonomi politik dan hukum yang negatif. Satu hal yang perlu diperhatikan dalam kaitannya dengan TKA adalah tidak adanya standar keahlian yang berlaku. Standar keahlian ini diperlukan untuk menyaring TKA yang datang ke Indonesia. Pemberlakuan standar profesi ini dapat menyeleksi kehadiran TKA tanpa melanggar kewajiban internasional dalam rangka komitmen di WTO. Secara umum pada negara anggota WTO (World Trade Organization) terutama negara maju sangat membatasi pergerakan tenaga kerja lintas negara. Berbeda pada mode 1 (cross border supply) dan mode 3 (commercial presence) yang agresif, negara maju cenderung membatasi komitmen MNP dari negara lain terutama untuk melindungi tenaga kerja domestiknya. Indonesia telah memiliki komitmen mode 4 mendasarkan pada economic need test dimana masuknya TKA didasarkan pada ada tidaknya kebutuhan atas TKA dimaksud, terutama untuk posisi manager dan technical expert. (Tim Perbankan \& Enquiry Point, 2007). Belum tercukupinya jumlah tenaga kerja Indonesia yang ahli dan terampil dalam mengantikan TKA dalam penggunaan/perawatan mesin-mesin canggih yang mengandung resiko tinggi (seperti dapat menimbulkan kerugian cukup besar materi maupun non materi jika tidak ditangani oleh para ahli) tersebut menjadi urgensi utama bagi banyak perusahaan multinasional di Indonesia (Mariana, Suharno, \& Hidayah, 2017).

Dilain sisi pemerintah Indonesia juga harus melindungi dan memproritaskan tenaga kerja dalam negeri agar tercipta kesinambungan antara perekonomian dan pasar kerja nasional. Sehingga selain membatasi penggunaan tenaga asing, Pemerintah dalam Perpes No. 20 Tahun 2018 tentang Penggunaan Tenaga Kerja Asing pada Pasal 26 juga mengatur mengenai kewajiban adanya pendampingan oleh Tenaga Kerja Indonesia kepada setiap TKA yang bekerja di Indonesia kecuali pada jabatan Direksi dan Komisaris. Hal tersebut dilakukan dengan tujuan untuk menjalankan proses "indonesianisasi" jabatan-jabatan yang diduduki oleh tenaga kerja asing dimana TKA menularkan segala keahliannya demi meningkatkan kualitas dan daya saing tenaga kerja nasional. Perusahaan pengguna TKA diwajibkan untuk melakukan alih keahlian dan teknologi dari TKA ke Tenaga kerja Indonesia yang ditunjuk sebagai Tenaga Kerja Pendamping dengan melaksanakan proses pendampingan serta pendidikan dan pelatihan bagi Tenaga Kerja Pendamping sesuai dengan kualifikasi jabatan yang diduduki oleh TKA yang didampinginya dan dibuktikan dengan sertifikat yang diterbitkan (Pasal 29 Perpres No.20 Tahun 2018). Keseluruhan pemenuhan persyaratan adanya alih keahlian dan teknologi melalui proses pendampingan serta pendidikan dan pelatihan bagi tenaga kerja pendamping, wajib disampaikan dalam permohonan pengesahan Rencana Penggunaan Tenaga Kerja Asing (RPTKA) (Pasal 7 Perpres No.20 Tahun 2018).

Dalam praktiknya, proses pendampingan TKA dalam rangka alih pengetahuan, keahlian, dan teknologi tersebut tidak berjalan seperti yang diharapkan. Seringkali kewajiban penunjukkan tenaga kerja pendamping TKA hanya dijadikan sebagai prasyarat administrasi saja dalam pengajuan izin RPTKA. Sehingga setelah izin didapatkan, perusahaan pemberi kerja TKA dan TKA yang dipekerjakan tidak benar-benar melaksanakan proses alih kehlian dan teknologi dari TKA kepada tenaga kerja 
Indonesia sebagai pendamping hingga selesainya masa kontrak kerja TKA. Selain itu, terdapat beberapa penyalahgunaan lain yang dilakukan oleh perusahaan pengguna TKA seperti mempekerjakan TKA tidak sesuai dengan RPTKA, penggunaan visa wisata untuk bekerja TKA, mempekerjakan TKA pada jabatan-jabatan yang tertutup bagi TKA menurut Kepmenaker No.40 Tahun 2012, hingga tidak melaporkan selesainya penggunaan TKA. Adanya perbedaan karakter dan core bisnis pada perusahaan pengguna TKA menjadikan kesulitan tersendiri dalam menjalankan kegiatan pendampingan TKA dengan efektif untuk alih pengetahuan, keahlian, dan teknologi dari TKA yang dipekerjakan ke Tenaga Kerja Pendamping.

Oleh karena itu, melalui penelitian ini akan dilakukan telaah lebih dalam untuk mengungkap bagaimana mekanisme pendampingan TKA selama ini di perusahaan pengguna TKA, mengidentifikasi mekanisme kegiatan pendampingan yang efektif dalam alih pengetahuan dan teknologi pada perusahaan pengguna TKA, apa saja kendala dan hambatan yang dihadapi Perusahaan dalam mencapai keberhasilan alih pengetahauan dan teknologi melalui pendampingan TKA, serta tindakan apa yang perlu dilakukan oleh pemerintah untuk melakukan otorisasi lebih konkrit mulai dari teknis pelaksanaan hingga pengawasan terhadapan proses pendampingan TKA.

\section{METODE PENELITIAN}

Metode penelitian berupa kualitatif deskriptif dengan mengumpulkan data dari tiga sektor masing-masing yang mendominasi perusahaan pengguna TKA di Yogyakarta yaitu jasa bidang pendidikan, jasa bidang teknologi, dan industri. Yogyakarta dipilih sebagai lokasi penelitian karena dianggap mampu memberikan refleksi secara menyeluruh dari masing-masing sektor atau bidang usaha perusahaan pengguna TKA yang ada di Indonesia. Secara teknis, pengumpulan data dilakukan dengan menggunakan kuisioner, wawancara yang berpedoman pada pertanyaan yang terstruktur serta Focus Group Discussion (FGD) dengan mengundang perwakilan perusahaan pengguna TKA yang dipilih sebagai narasumber dari masing-masing sektor tersebut. Narasumber FGD adalah Tenaga Kerja pendamping TKA yang berstatus sebagai pegawai tetap dan perwakilan Divisi Human Resource Development (HRD) perusahaan pengguna TKA terbesar di Yogyakarta.

\section{HASIL DAN PEMBAHASAN}

\section{A. Perkembangan TKA di Indonesia}

Sejak tahun 2008-2019, jumlah TKA bekerja di Indonesia memiliki pertumbuhan rata-rata per tahun sebesar 10,15\%. Berdasarkan data yang diperoleh dari BKPM, di periode yang sama realisasi investasi Penanaman Modal Asing (PMA) setiap tahun hanya tumbuh di angka 9,49\%. Kondisi ini menunjukkan bahwa ratarata meningkatnya TKA yang bekerja tidak sebanding dengan pertumbuhan nilai investasi yang dibawanya ke Indonesia pada perioide setiap tahunnya atau negatif sebesar $0,66 \%$ realisasi investasi PMA dibandingkan TKA yang bekerja seperti yang ditunjukkan pada tabel 1.

Jika dicermati lebih dalam nilai realisasi investasi PMA di Indonesia terbesar berada di negara-negara Asia sejak tahun 2010 dengan kontributor negara penginvestasi terbesar di tahun 2019 berasal dari Singapura sekitar $25.39 \%$ dari total investasi asing di Indonesia dengan nilai investasi sebesar 5.380.517 (US\$. Ribu). Negara pemberi modal asing terbesar kedua adalah Tiongkok China dengan nilai investasi sebesar 3.313.272 (US\$. Ribu) atau menguasi sebesar $15,64 \%$ dari total investasi PMA di Indonesia. Sementara itu, negara Jepang dan Belanda menempati urutan ketiga dan keempat investor asing terbesar di Indonesia dengan nilai investasi sebesar 3.239.859 (US\$. Ribu) dan 2.096.532 (US\$. Ribu) seperti yang terlihat dalam gambar 1. Mengalirnya dana PMA membawa konsekuensi masuknya Tenaga Kerja Asing (TKA) ke Indonesia. Beberapa proyek yang menggunakan teknologi baru dan belum bisa dikerjakan oleh pekerja lokal tentu membutuhkan TKA dari negara asal. Mereka bekerja sebagai teknisi maupun tenaga ahli sebelum dilakukan alih teknologi.

Sejalan dengan peningkatan PMA, tren jumlah TKA selalu meningkat dari tahun ke tahun. Pada Desember 2019, tercatat sebanyak 95.335 TKA terdaftar bekerja di Indonesia yang ditunjukkan dengan kepemilikan IMTA. Selama 11 tahun terakhir jumlah TKA yang bekerja di Indonesia mengalami pertumbuhan hampir 240\% dari 32.918 TKA pada tahun 2007. Apabila dilihat berdasarkan negara asalnya, 
jumlah TKA terbanyak disumbang oleh China dan sudah terjadi sejak tahun 2010. Ditahun tersebut jumlah TKA dari China tercatat sebesar 9.902 orang atau menguasai sekitar $20.8 \%$ dari total TKA di Indonesia. Sementara itu, di tahun 2019 jumlah TKA dari China telah mencapai 42.624 TKA atau setara dengan 39\% dari total TKA di Indonesia. Sehingga disimpulkan jumlah TKA dari China di Indonesia telah tumbuh sebesar $330.45 \%$ dalam kurun waktu 9 tahun. Selain berasal dari negara China, posisi jabatan TKA yang bekerja di Indonesia juga diisi oleh negara-negara lainnya seperti Amerika Serikat, Australia, India, Inggris, Jepang, Korea Selatan, Malaysia, Filipina, singapura, dan lainlain. Tingginya jumlah TKA dari negara-negara tersebut selain disebabkan oleh banyaknya investasi PMA ke Indonesia juga didorong oleh relatif tingginya pertumbuhan ekonomi Indonesia selama beberapa tahun terakhir. Pertumbuhan ekonomi tersebut termasuk di sektor keuangan/pasar modal yang membutuhkan tenaga-tenaga kerja berkelas internasional.

\begin{tabular}{|c|c|c|c|c|}
\hline \multicolumn{5}{|c|}{ Tabel 1. Realisasi Investasi PMA dan Jumlah IMTA } \\
\hline Tahun & $\begin{array}{l}\text { PMA Investasi } \\
\text { (US\$. Ribu) }\end{array}$ & Growth & IMTA & Growth \\
\hline 2007 & $10.409 .083,80$ & $0,00 \%$ & $32.918,00$ & $0,00 \%$ \\
\hline 2008 & $17.561 .060,40$ & $68,71 \%$ & $38.634,00$ & $17,36 \%$ \\
\hline 2009 & $12.574 .517,20$ & $-28,40 \%$ & $41.459,00$ & $7,31 \%$ \\
\hline 2010 & $16.214 .772,30$ & $28,95 \%$ & $47.641,00$ & $14,91 \%$ \\
\hline 2011 & $19.442 .257,00$ & $19,90 \%$ & $55.515,00$ & $16,53 \%$ \\
\hline 2012 & 24.564.670,20 & $26,35 \%$ & $60.670,00$ & $9,29 \%$ \\
\hline 2013 & 28.617.506,10 & $16,50 \%$ & $70.120,00$ & $15,58 \%$ \\
\hline 2014 & $28.529 .698,50$ & $-0,31 \%$ & $73.624,00$ & $5,00 \%$ \\
\hline 2015 & $29.275 .940,00$ & $2,62 \%$ & $77.149,00$ & $4,79 \%$ \\
\hline 2016 & $28.964 .074,80$ & $-1,07 \%$ & $80.375,00$ & $4,18 \%$ \\
\hline 2017 & $32.239 .751,80$ & $11,31 \%$ & $85.974,00$ & $6,97 \%$ \\
\hline 2018 & $28.218 .198,20$ & $-12,47 \%$ & $95.335,00$ & $10,89 \%$ \\
\hline 2019 & $21.188 .049,20$ & $-24,91 \%$ & $109.546,00$ & $14,91 \%$ \\
\hline Mean Growth & \multicolumn{2}{|l|}{$9,49 \%$} & \multicolumn{2}{|c|}{$10,15 \%$} \\
\hline
\end{tabular}

Sumber: BKPM, Direktorat Penggunaan Tenaga Kerja Asing (diolah)

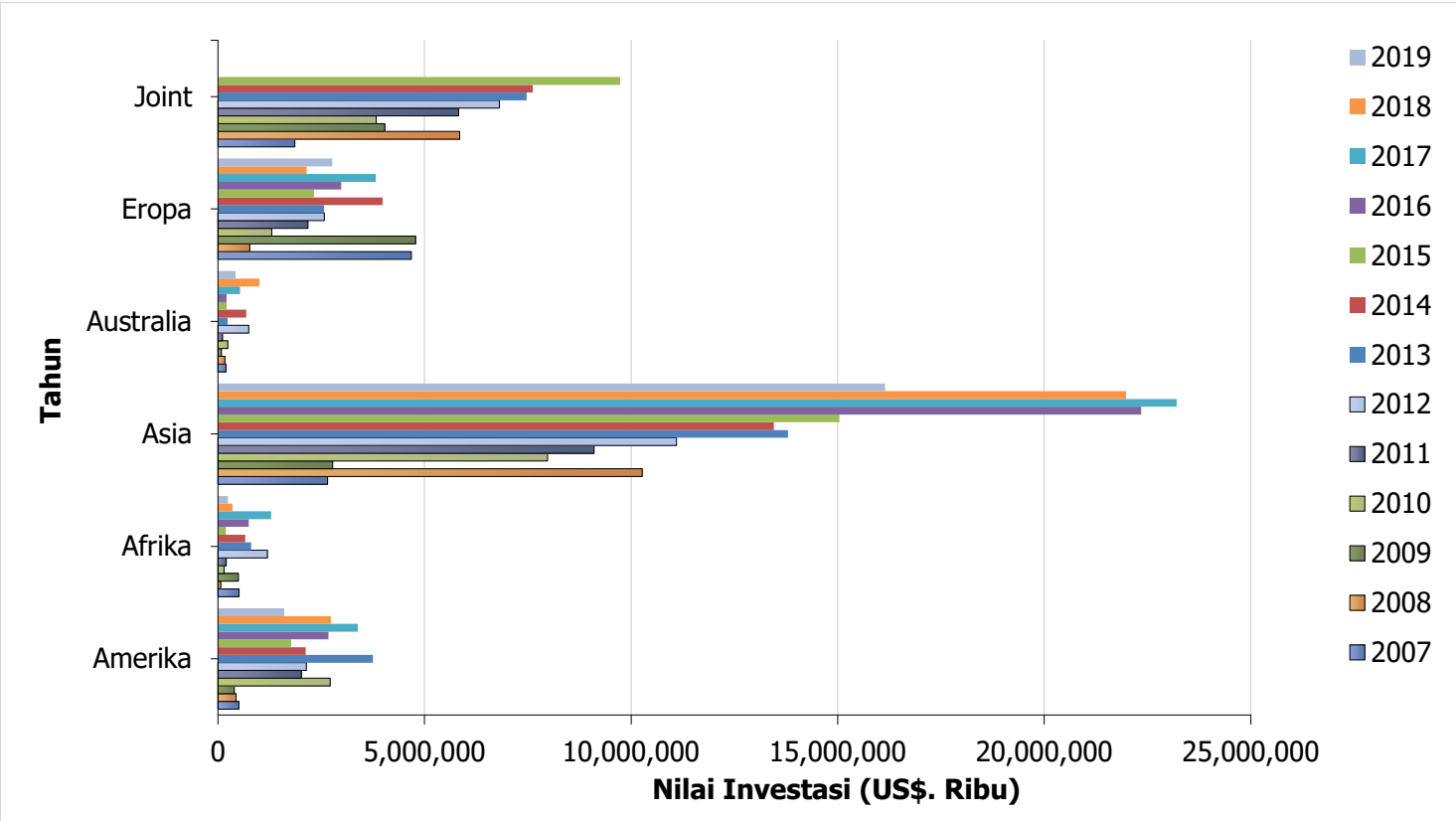

Gambar 1: Perkembangan Realisasi Investasi PMA Berdasarkan Negara Periode 2007-2019 Sumber: Badan Koordinasi Penanaman Modal (diolah). 
Jika diurutkan mayoritas TKA yang bekerja yaitu sebagai tenaga profesional sebanyak 30.626 orang atau sekitar 32\% dari total TKA, sebagai manajer sebanyak 21.237 orang dan advisor/consultant sekitar 15.636 orang. Sisanya bekerja pada jabatan sebagai direksi, teknisi, supervisor, dan komisaris. Hal tersebut menunjukkan bahwa jabatan yang paling diminati oleh TKA di Indonesia berada pada level jabatan Profesional yang telah terjadi selama 10 tahun lebih. Tingginya pekerja TKA profesional di Indonesia mulai terjadi sejak awal tahun 2007. Sedangkan pada periode sebelum tahun 2007, jabatan TKA di Indonesia lebih didominasi oleh konsultan. Hal ini mengindikasikan terjadinya pergeseran jabatan pada pola rekrutmen TKA dari jabatan

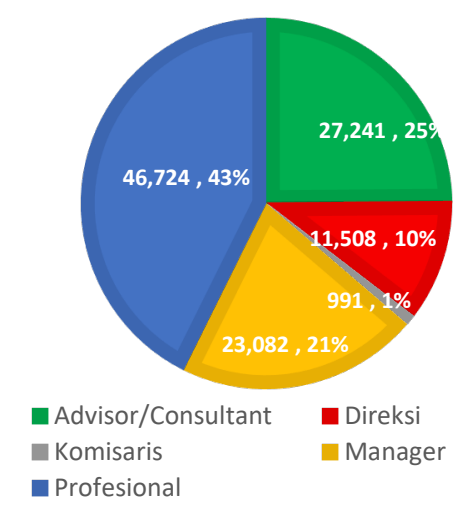

konsultan ke jabatan profesional. Pergeseran ini terjadi disebabkan perusahaan pada awalnya lebih banyak menggunakan TKA sebagai tenaga konsultan baik sebagai konsultan manajemen, finansial, SDM hingga konsultan teknologi. Namun sejalan dengan perkembangan pengetahuan dan teknologi, kebutuhan terhadap bidang yang selama ini ditangani oleh konsultan ternyata membutuhkan kehadiran seorang yang ahli di bidangnya secara lebih permanen. Oleh karena itu, beberapa perusahaan pengguna TKA kemudian menawarkan konsultan asing tersebut untuk menjadi tenaga profesional yang diperlakukan seperti pegawai internal perusahaan (Yudanto, Prasetyo, Nugroho, \& Sadha, 2010).

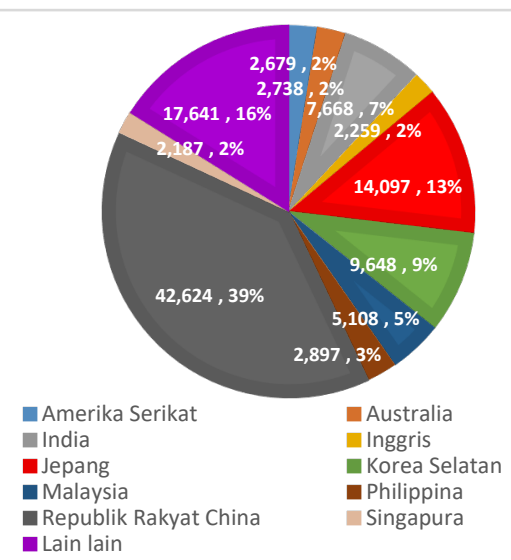

Gambar 2. TKA Berdasarkan Negara dan Jabatan Tahun 2019

Sumber: Direktorat Penggunaan Tenaga Kerja Asing (diolah)

\section{B. Karakteristik TKA, TK Pendamping \& Perusahaan Pengguna TKA di Yogyakarta}

Berdasarkan data responden dalam penelitian ini mayoritas perusahaan pengguna TKA di Yogyakarta merupakan perusahaan permodalan Penanaman Modal Asing (PMA) yaitu sebesar $56 \%$ dari total perusahaan Pengguna TKA di tahun 2018. Berdasarkan Pasal 1 UU No.25 Tahun 2007 tentang Penanaman Modal, arti dari Penanaman Modal Asing (PMA) adalah kegiatan menanam modal untuk melakukan usaha di wilayah NKRI yang dilakukan oleh penanam modal asing, baik menggunakan modal asing sepenuhnya maupun hasil berpatungan dengan penanam modal dalam negeri. Perusahaan pengguna TKA di Yogyakarta tersebut sebesar $56 \%$ bergerak pada sektor usaha Industri dan 44\% pada sektor Jasa. Kondisi ini menjukkan bahwa perusahaan asing yang masuk ke Yogyakarta dalam rangka berinvestasi modal dan/atau melakukan usaha akan turut membawa TKA didalamnya. Berdasarkan data (Tim Publikasi Katadata, 2019), satu investasi menciptakan satu TKA berbanding sembilan tenaga kerja lokal dimana sebagian besar TKA datang hanya untuk pemasangan peralatan mesin-mesin yang menggunakan bahasa Jepang atau Mandarin atau bahasa yang berasal dari Negara mereka masing-masing dan bertahan dalam jangka waktu yang singkat.

Berdasarkan kondisi tersebut, pemerintah telah mengantisipasi dengan mewajibkan setiap Perusahaan pengguna TKA menyediakan TK Pendamping (TKI) untuk melakukan alih keahlian, pengetahuan, dan teknologi dari TKA yang dipekerjakannya. Transfer ilmu, keahlian dan teknologi dari TKA ke TK pendamping (TKI) wajib dilakukan oleh Perusahaan Pengguna TKA selama masa kontrak kerja TKA di Perusahaan, dengan target adanya peningkatan kualitas dan kapasitas kerja TK Pendamping hingga mampu menggantikan 
seluruh peran serta tugas dari TKA yang didampinginya. Dalam praktiknya keberhasilan kegiatan pendampingan TKA tidak mudah dilakukan. Pada penelitian ini, perbedaan karakteristik personal banyak ditemukan antara TK Pendamping dan TKA seperti usia, pendidikan, dan jenis kelamin. Pada Gambar 4 menunjukkan bahwa mayoritas TK Pendamping berusia 31-45 tahun berada pada level yang sama dengan mayoritas usia TKA. Hal tersebut menunjukkan bahwa Perusahaan pengguna TKA lebih banyak mempekerjakan TKA pada usia produktif yang telah memiliki kematangan pengalaman dan keahlian kerja. Sebab membangun sebuah perusahaan dengan sistem baru di negara yang memiliki banyak perbedaan ekosistem, kondisi geografis, lingkungan, sosial, dan bahkan budaya dibandingkan di negara asalnya (Thomas \& Prétat, 2009; Davenport \& Prusak, 2000), akan menciptakan masalah pada tingkat kesulitan yang sangat tinggi, sehingga diperlukan para ahli dibidangnya untuk dapat bekerja dimana lokasi tujuan investasi. Sementara itu, perusahaan pengguna TKA justru cenderung memilih TK pendamping dengan usia relatif muda agar lebih cepat menyerap proses pembelajaran yang diberikan oleh TKA selama kegiatan pendampingan berlangsung. Secara umum tenaga kerja muda bergerak lebih energik dan adaptif dalam menghadapi pesatnya kemajuan teknologi dibandingkan dengan generasi-generasi sebelumnya.
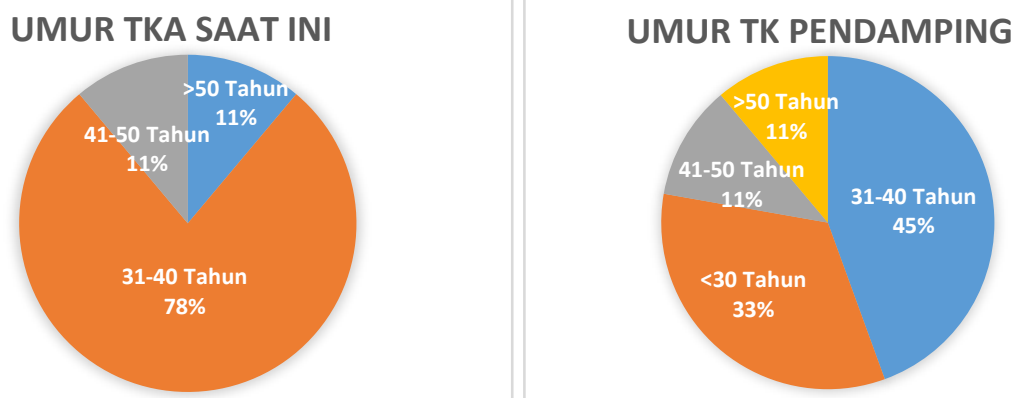

\section{Gambar 3. Komposisi Umur TKA dan Umur TK Pendamping}

Sumber: Data Primer (diolah)

Jika dilihat dari jenis kelamin, dominasi perempuan sebagai TK Pendamping lebih besar dibandingkan dengan laki-laki (56:46). HRD perusahaan pengguna TKA dalam nyatanya lebih banyak menunjuk Perempuan sebagai TK Pendamping karena karakteristik perempuan dinilai lebih luwes/sabar menerima dan menyesuaikan banyaknya perbedaan yang timbul dengan TKA yang didampinginnya (seperti suku, budaya, agama, adat-istiadat, dan sebagainya) yang seringkali rawan menimbulkan konflik batin diantara keduanya. Lain halnya dengan mayoritas TKA yang didominasi oleh jenis kelamin laki-laki sebesar $89 \%$, disebabkan oleh keahlian pada jabatanjabatan yang paling dibutuhkan oleh Perusahaan pengguna TKA adalah jabatan mayoritas lakilaki di negara asalnya.

Pada tingkat pendidikan, mayoritas responden di Yogyakarta memiliki kesesuaian pendidikan terakhir yang ditamatkan baik TKA maupun TK Pendamping yaitu berada pada level setingkat S1. Meskipun TKA yang ada di Yogyakarta memiliki tingkat pendidikan tertinggi yang lebih baik dibandingkan TK Pendamping, dimana $22 \%$ populasi TKA terdiri dari lulusan setingkat S3 sementara tingkat pendidikan tertinggi yang dimiliki oleh TK Pendamping adalah S2, namum tingkatan pendidikan TK Pendamping tersebut telah cukup memiliki kompetensi dan kapasitas yang mumpuni dalam mendampingi TKA melakukan alih pengetahuan dan teknologi.

Seluruh TKA yang bekerja di Yogyakarta mampu berbahasa Indonesia dengan baik dan menguasai bahasa asing lainnya seperti bahasa Inggris, Belgia, Prancis, Korea, Spanyol, dan Yunani. Kemampuan bahasa menjadi faktor kunci sebuah kegiatan pendampingan dapat berjalan efektif atau tidak dengan melihat apakah alih keahlian, pengetahuan dan teknologi dapat diterima secara utuh oleh para TK Pendamping. Agar mampu menjalankan standar kualitas dan kompetensi terbaik disetiap jabatan pekerjaannya, TKA pada proses perekrutan telah dipersyartkan memiliki sertifikasi kompetensi yang berlaku secara global atau memiliki pengalaman kerja minimal lima tahun sesuai dengan kualifikasi yang akan diduduk oleh TKA (Republik Indonesia, 2018). Namun kewajiban memiliki sertifikasi kompetensi bagi setiap calon TK Pendamping menjadi hal yang 
sulit diaplikasikan di Yogyakarta khususnya, bahkan di Indonesia pada umumnya. Selain karena mahalnya biaya pengadaan sertifikasi keahlian tersebut, beberapa jabatan yang berlaku di Indonesia juga belum seluruhnya memiliki regulasi memadai mengenai sertifikasi kompetensi. Berdasarkan hasil penelitian ini menunjukkan sebesar $71 \%$ TK Pendamping

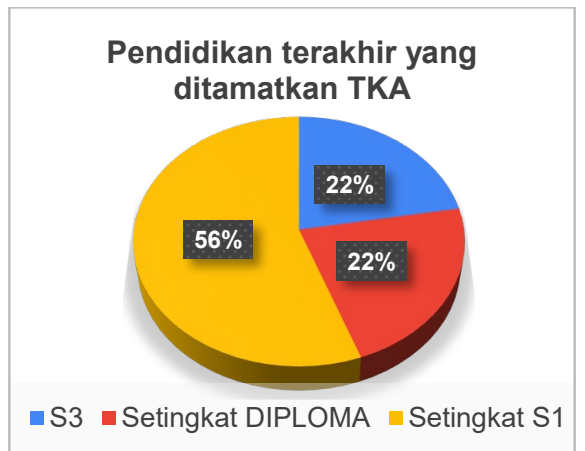

yang bekerja di Yogyakarta tidak memiliki sertifikasi kompetensi, kecuali beberapa profesi yang telah diatur oleh regulasi terkait bidang keahliannya untuk mewajibkan sertifikasi keahlian sebagai salah satu syarat kerja, seperti pada profesi/jabatan dosen yang telah terikat kewajiban memiliki sertifikasi keahlian mengajar dari DIKTI.

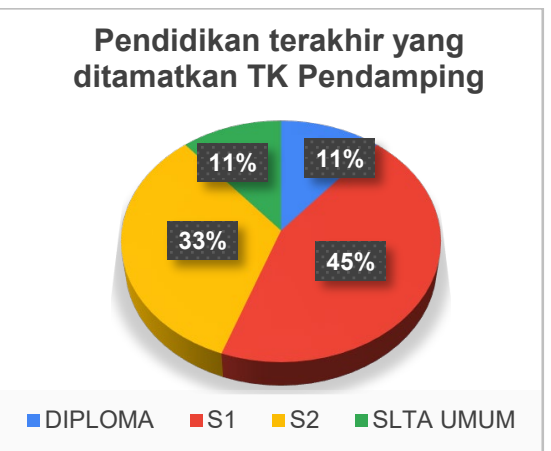

Gambar 4. Tingkat Pendidikan Terakhir TKA dan TK Pendamping

Sumber: Data Primer (diolah)

\section{Mekanisme Penunjukan Tenaga Kerja Pendamping}

Beberapa HRD perusahaan pengguna TKA di Yogyakarta melakukan proses pemilihan TK Pendamping melalui cara yang beragam. Ada yang mengawali dengan (1) menanyakan kepada calon TK Pendamping kesediaan untuk menjadi tenaga kerja pendamping dan motivasi untuk berkembang, (2) dipilih langsung oleh pimpinan dan disesuaikan dengan kemampuan dan bidang ilmu TKA, (3) pemilihan berdasarkan kualifikasi jabatan yang berhubungan erat dengan jabatan TKA, background pendidikan dan status kepegawaian, (4) menyesuaikan dengan jobdesk TKA. Seleksi dan perekrutan TK Pendamping yang dilakukan perusahaan Pengguna TKA di Yogyakarta secara umum mensyaratkan ketentuan administrasi seperti merupakan pekerja berstatus karyawan tetap, memiliki bidang ilmu yang sesuai dengan TKA, memiliki karakter komunikatif dan aktif, pendidikan minimal D3 atau Sarjana, pernah atau sedang menjabat pekerjaan yang berhubungan erat dengan tugas jabatan TKA, bersedia menjadi tenaga pendamping, mempunyai skill \& kompetensi di bidang yang sama dengan tugas pendampingan TKA, memiliki kemampuan berbahasa inggris atau bahasa asing lainnya dengan baik sebagai kriteria utama, dan lain sebagainya.

\section{Efektivitas Dan Teknis Pelaksanaan Kegiatan Pendampingan TKA}

Evaluasi dalam pelaksanaan dan teknis pendampingan yang dijalankan Perusahaan pengguna TKA di Yogyakarta ditemukan seperti, belum adanya pedoman baku mengenai teknis pelaksanaan dan standar umum pelaksanaan kegiatan pendampingan TKA untuk perusahaan pengguna TKA, mengakibatkan kebingungan hingga ketidakseragaman pelaksanaan kegiatan pendampingan TKA pada bidang usaha yang sama. Sebanyak 86\% Perusahaan Pengguna TKA ditemukan tidak memiliki SOP khusus yang mengatur mengenai pelaksanaan kegiatan pendampingan dan sisanya merupakan perusahaan yang telah mengatur pelaksanaan kegiatan pendampingan dalam bentuk Internal Memo (memiliki kekuatan pengikat yang lebih kecil dibandingkan dengan SOP). Sebelum kegiatan pendampingan TKA dimulai, perusahaan melalui HRD melakukan dialog atau sharing session kepada TKA beserta TK Pendamping sebagai bentuk orientasi sekaligus brainstorming agar mencapai maksud \& tujuan yang sama dan jelas terkait pelaksanaan kegiatan pendampingan tersebut dan mengurangi adanya konflik kepentingan diantara TKA dan TK Pendamping. Output dari orientasi dan brainstorming tersebut adalah sebuah logbook Pendampingan atau dokumen berisi detil butir-butir target kegiatan pendampingan TKA yang harus dicapai pada setiap periode tertentu selama proses pendampingan berlangsung. Pertemuan 
brainstorming menjadi salah satu poin penting yang menjamin suksesnya alih pengetahuan (Thomas \& Prétat, 2009).

Jika berkaitan dengan waktu mulai pelaksanaan pendampingan ditemukan sebesar 78\% Perusahaan telah melakukan kegiatan pendampingan TKA sejak awal hingga tiga bulan pertama TKA bekerja. Sementara itu, sebanyak 22\% Perusahaan justru tidak langsung memulai kegiatan pendampingan TKA, tetapi baru melakukan pendampingan saat bulan ke-12 lebih sejak TKA bekerja. Adanya jeda waktu antara pelaksanaan pendampingan dengan mulai bekerjanya TKA pada beberapa perusahaan disebabkan oleh proses perekrutan TK Pendamping yang cenderung membutuhkan

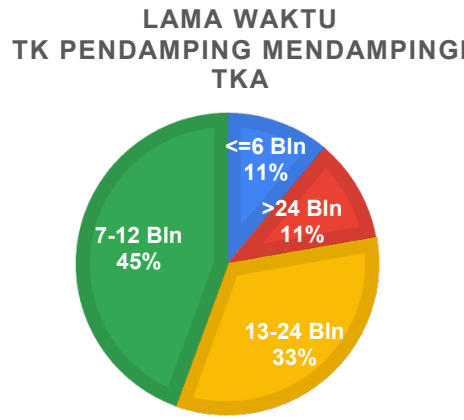

waktu lebih lama dibandingkan perekrutan TKA itu sendiri, dengan sumberdaya yang ada untuk mencapai kecocokan dan mengecilkan gap diantara keduanya. Kesulitan terbesar yang dihadapi dalam mencari TK Pendamping adalah kemampuan berbahasa asing calon TK Pendamping yang sangat minim dan terbatas. Ketika diantara mereka memiliki kualifikasi kompetensi yang tinggi sesuai dengan TKA tetapi terkendala kemampuan bahasa inggris yang tidak baik, dan begitu juga sebaliknya saat perusahaan menemukan seorang calon TK Pendamping yang mampu berbahasa inggris tetapi tidak memiliki kualifikasi kompetensi yang sesuai dengan TKA yang akan didampingi.

\section{Gambar 5. Lama Waktu \& Lama Rata-Rata Jam Per Minggu TK Pendamping Bekerja Bersama-Sama Dengan TKA}

Sumber: Data Primer (diolah)

Jangka waktu kegiatan pendampingan TKA hingga terjadinya alih keahlian dan teknologi dari TKA ke TK Pendamping dilakukan oleh rata-rata Perusahaan pengguna TKA adalah selama 7-12 bulan. Sementara itu, 56\% dari perusahaan pengguna TKA di Yogyakarta memiliki lama rata-rata kurang dari 11 jam dalam seminggu TK Pendamping bekerja bersama-sama dengan TKA dan 33\% memiiki rata-rata 11-30 jam per minggu. Sehingga dapat disimpulkan bahwa mayorittas TK Pendamping di Yogyakarta mulai melakukan kegiatan pendampingan sejak bulan pertama hingga bulan ketiga TKA bekerja dengan lama waktu pendampingan 7-12 bulan dan kurang dari 10 jam dalam seminggu terlihat dalam gambar 5 .

Selain itu, pada pelaksanaan kegiatan pendampingan sebesar $71 \%$ perusahaan pengguna TKA di Yogyakarta menugaskan TK Pendamping yang telah memiliki kualifikasi keahlian dan keterampilan yang sesuai dengan TKA yang didampinginya. Penelitian terdahulu menyarankan kesamaan heuristik dan kesamaan pengalaman antara sumber dan penerima merupakan antaseden penting dari alih pengetahuan (Ko, Kirsch, \& King, 2005). Namun, beberapa perbedaan mencolok ditemukan antara TK Pendamping dan TKA dan seringkali menjadi hambatan utama dalam melakukan alih pengetahuan dan teknologi (Sangkala, 2007). Seperti adanya perbedaan etos kerja dimana TKA memiliki tingkat yang tinggi dalam kedisiplinan terutama waktu, sifat pantang menyerah, bekerja keras, terencana dan terukur dengan sangat matang sebelum melakukan segala sesuatu pekerjaan, dan berkomitmen tinggi. Perbedaan lingkungan sosial-budaya juga menentukan bagaimana proses pendampingan dan pertukaran informasi dapat diserap dengan baik oleh keduanya tanpa adanya kesalahpahaman pesan yang ingin disampaikan, seperti TKA perlu memahami bagaimana masyarakat Indonesia masih sangat menjunjung tinggi nilai kesopanan dan adat istiadat yang luhur dalam menjalankan kehidupan sehari-hari dan bermasyarakat sehingga budaya asing yang dibawa TKA tidak sebaiknya diterapkan dalam kehidupan bermasyarakat di Indonesia. Selain itu, perbedaan kondisi geografis di Indonesia yang 
merupakan negara berkembang dengan keterbatasan fasilitas dan teknologi sekaligus negara maritim berisi gugusan kepulauan dan keanekaragaman alamnya, menjadikan medan geografis Indonesia lebih sulit untuk dijangkau dibandingkan negara-negara lain pada umumnya.

Metode alih pengetahuan melalui kegiatan pendampingan TKA yang dilakukan oleh Perusahaan Pengguna TKA di Yogyakarta terdiri dari on the job training dan off the job training. On the job training adalah proses pelaksanaan pendampingan TKA bersamaan pada saat itu juga TK Pendamping mengikuti secara langsung dan dilibatkan dalam pekerjaan TKA sehari-hari. Sementara off the job training adalah proses pelaksanaan pendampingan TKA yang dilakukan tidak bersamaan pada saat itu juga TKA melakukan pekerjaannya atau TK Pendamping mendapatkan pengajaran pada waktu dan tempat tersendiri diluar rutinitas pekerjaan yang dilakukan TKA sehari-hari. Salah satu contoh metode off the job training yang dilakukan yakni diadakannya pertemuan rutin di ruang rapat perusahaan untuk berdiskusi bersama membahas perkembangan kinerja dari tupoksi masing-masing TKA \& TK Pendamping selama kegiatan pendampingan TKA berlangsung atau diisi dengan saling

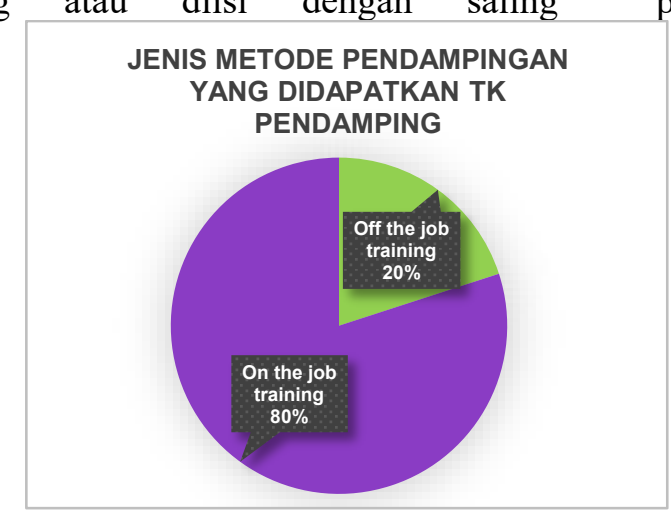

\section{Gambar 6. Jenis Metode Pendampingan Yang Didapatkan TKA dan Kombinasi Penerapan Metode Pendampingan}

Sumber: Data Primer (diolah)

Efektivitas alih pengetahuan dan teknologi dalam pendampingan TKA di Yogyakarta pada sisi komunikasi ditemukan bahwa semua Informasi dan pesan penting dari TKA dapat dipahami dengan baik oleh TK Pendamping menggunakan bahasa lisan atau tanpa berkomunikasi dengan menggunakan bahasa isyarat selama kegiatan program pendampingan. Interaksi diantara TKA dan TK Pendamping pun terjalin dengan baik dimana TKA yang didampingi aktif menjelaskan keahlian yang memberikan pengajaran/paparan satu sama lain antara TKA ke TK Pendamping dan sebaliknya. Pertemuan rutin yang berjenis rapat unit bisnis, rapat pertukaran informasi, rapat brainstorming, simposium, dan pertemuan tatap muka, menjadi salah satu alat utama suksesnya alih pengetahuan di Perusahaan selain bimbingan belajar (Thomas \& Prétat, 2009). Alih pengetahuan dengan mengkolaborasikan beberapa metode seperti on-the-job-training, job rotation, dan seluler organisasi/tim dapat juga terjadi (Lahti \& Beyerlein, 2000).

Berdasarkan hasil penelitian sebesar $80 \%$ TK Pendamping mendapatkan metode pendampingan secara on the job training dari TKA yang didampinginya, sementara sisanya didapatkan melalui metode off the job training. Modifikasi diantara kedua metode tersebut sangat dimungkinkan untuk diterapkan secara bersamaan selama kegiatan pendampingan TKA berlangsung. Hasil penelitian menemukan masing-masing sebesar $43 \%$ Perusahaan yang menerapkan metode on the job training lebih besar dari $80 \%$ dengan kombinasi off the job training kurang dari $20 \%$, serta sebesar $51 \%$ $80 \%$ perusahaan yang menerapkan metode on the job training dengan kombinasi metode sebesar 20\%-49\% off the job training seperti pada gambar 6 .

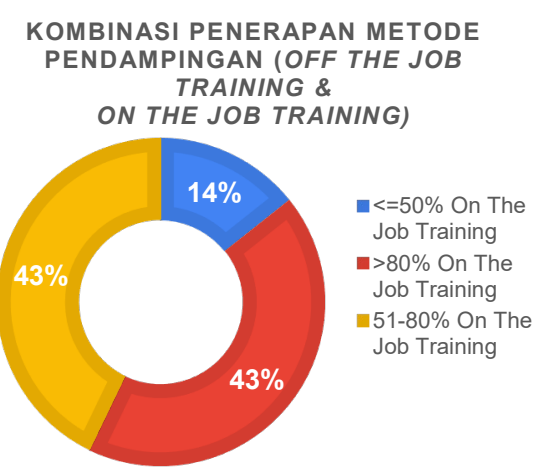

dimikinya dan TK Pendamping juga aktif bertanya kepada TKA yang didampingi. Model komunikasi yang dilakukan TK Pendamping dan TKA seimbang antara tindakan dan lisan dengan pokok pembicaraan yang tidak sering membicarakan hal pribadi di luar pekerjaan. Komunikasi menjadi tidak memiliki kesulitan yang lebih besar dibandingkan dengan pekerjaan yang TK Pendamping harus kuasai.

Pada sisi skill dan knowledge sejak menjadi pendamping TKA, keahlian TK Pendamping 
menjadi cukup bertambah seperti kemampuan problem solving TK Pendamping yang cukup meningkat sejak mendampingi TKA, kemampuan berbahasa asing TK Pendamping cukup bertambah setelah pendampingan, dan TK Pendamping menjadi lebih teliti dalam menjalankan pekerjaan. Selain keahlian inti dalam jabatan TKA, TK Pendamping juga cukup memperoleh keahlian lain dari TKA yang didampinginya. Sementara TKA yang didampingi memiliki kemampuan diatas TK Pendamping, menurut TK Pendamping, tidak banyak pekerja di Indonesia yang bisa menggantikan TKA yang mereka dampingi. Sejak awal, TK Pendamping cukup menyadari bahwa memiliki kemampuan yang sama atau sejenis dengan TKA yang sedang didampingi dan TKA yang didampingi sangat mudah untuk berbagi kepada TK Pendamping. TKA yang didampingi cukup mempercayakan sebagian pekerjaannya kepada TK Pendamping sehingga pengetahuan teknis TK Pendamping menjadi cukup bertambah setelah pendampingan.

Pada sisi attitude, kegiatan pendampingan TKA cukup menjadikan TK Pendamping semakin rajin bekerja dan tidak terlambat datang ke kantor setelah menjadi pendamping TKA. Selain itu, TK Pendamping menjadi cukup lebih bijaksana dan cukup memiliki motivasi dan kecenderungan yang kuat dalam menyikapi permasalahan terkait pekerjaannya. TK Pendamping memiliki karakteristik yang cukup terbuka terhadap inovasi yang muncul dalam pekerjaannya dan memiliki perubahan pola pikir

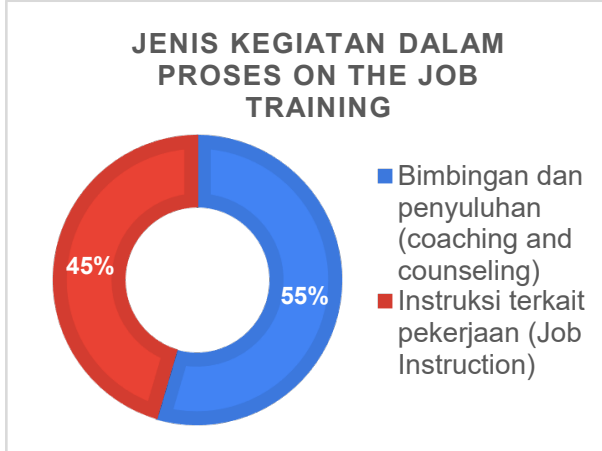

dalam melihat suatu masalah terkait dengan pekerjaan. Hal tersebut dapat terjadi karena TKA yang didampingi memiliki keterbukaan diri atau tidak individualis serta etos kerja yang tinggi. Sementara TK Pendamping memiliki karakter yang mudah dalam mengikuti pola kerja TKA yang didampingi.

\section{E. Metode Ideal Alih Pengetahuan dan Teknologi Melalui Kegiatan Pendampingan}

Berdasarkan hasil penelitian kegiatan pendampingan TKA di Yogyakarta ditemukan bahwa kombinasi antar kedua metode tersebut mampu memberikan hasil yang lebih baik untuk melakukan alih pengetahuan dan teknologi di dalam kegiatan pendampingan, dibandingkan hanya memilih salah satu metode saja untuk diterapkan. Kombinasi terbaik diisi dengan mayoritas kegiatan dalam bentuk on the job training sekitar $80 \%$ dan $20 \%$ off the job training dengan jenis kegiatan yang banyak dilakukan dalam pendampingan TKA dan dinilai paling efektif dalam metode on the job training adalah dengan kegiatan bimbingan dan penyuluhan (coaching and counceling) serta instruksi terkait pekerjaan (job instruction) seperti pada gambar 7. Pengetahuan eksplisit sebagian besar ditransfer dengan bantuan sarana teknologi dan pengetahuan diam-diam melalui metode seperti pembinaan, konseling, pemodelan, mendongeng dan pelatihan (Lahti \& Beyerlein, 2000).

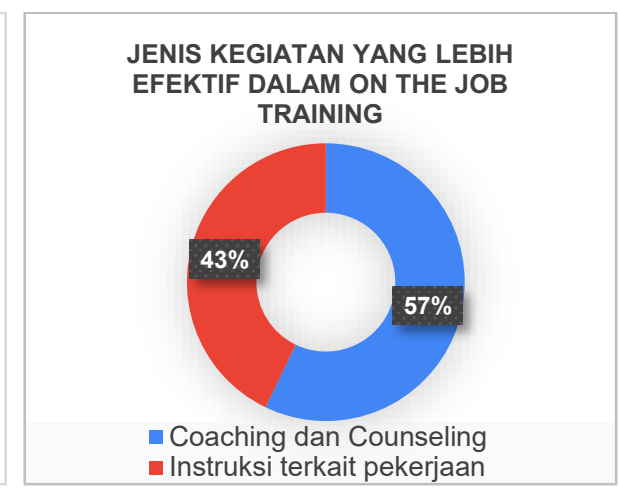

Gambar 7. Jenis Kegiatan On The Job Training Dan Yang Paling Efektif Dilakukan Sumber: Data Primer (diolah)

Selain itu, ditemukan juga keberhasilan alih pengetahuan, keahlian dan teknologi pada kegiatan pendampingan TKA di Yogyakarta terjadi melalui hubungan informal yang dibangun diluar jam kerja dan hubungan kerja. Berdasarkan penelitian sebelumnya menyebutkan bahwa salah satu faktor penting memudahkan terjadinya alih pengetahuan adalah hubungan antara seorang narasumber dan seorang penerima (Argote, 1999; dikutip Ko, Kirsch, \& King, 2005).

Mengalihkan pengetahuan memerlukan interaksi yang berulangkali antar orang yang terlibat (Nonaka, 1994; Ko, Kirsch, \& King, 
2005). Kesuksesan interaksi bergantung pada kualitas hubungan (Ko, Kirsch, \& King, Antecedents of Knowledge Transfer from Consultations to Clients, 2005). Keeratan/Keakraban psikologi yang berhasil dibangun dengan baik sejak awal perkenalan hingga proses pendampingan selesai, akan memudahkan penyampaian arti/pesan secara utuh serta memahami setiap pengajaran ilmu yang diberikan selama pendampingan. Kekakuan hubungan (arduous relationship) didefinisikan sebagai hubungan yang sulit secara emosional dan hubungan yang jauh antara unit sumber dengan unit penerima dan akan mengurangi keefektifan alih pengetahuan (Szulanski, 1996; Ko, Kirsch, \& King, 2005). Seringkali perbedaan budaya yang kental dibawa oleh TKA dari masing-masing negaranya memberikan sekat yang jauh dengan TK Pendamping seperti perbedaan pola pikir yang berujung pada kesalahpahaman arti yang ditangkap dalam komunikasi diantara mereka. Alih pengetahuan terjadi ketika bagaimana kemampuan kontributor mengalihkan pengetahuan yang diperlukan kepada adapter untuk mempelajarinya serta menggunakan pengetahuan tersebut. Dalam kegiatan pendampingan pertukaran informasi tidak hanya dilakukan dari TKA saja tetapi TK pendamping juga turut serta dan wajib melakukan alih pengetahuan kepada TKA yang didampinginya seperti memperkenalkan budaya dan kondisi geografis Indonesia (khususnya Yogyakarta dalam konteks penelitian ini), dan lain sebagainya. Sehingga timbal balik dan kerjasama yang baik dari TKA maupun TK Pendamping harus dilakukan bersama-sama demi membangun ikatan emosional yang erat/akrab dan harmonis.

Oleh karena itu, kegiatan-kegiatan informal sengaja dilakukan secara rutin untuk membangun ikatan emosional lebih erat dan kesepahaman antara TKA dan TK Pendamping. Kegiatan informal diluar jam kerja tersebut diisi dengan kegiatan keakraban dan kegiatan kesukaan masing-masing, seperti bersepeda pagi bersama, naik gunung bersama, diskusi santai di café atau hanya sekedar mengadakan "Potluck", dimana setiap orang TKA dan TK Pendamping saling memberikan kontribusi makanan khas dari negara masing-masing untuk dibagibagikan di antara grup. Makan minum seadanya dengan membawa dan membagikan piring dan gelas untuk masing-masing dari mereka. Kegiatan tersebut dapat menjadi sarana untuk menyatukan dua budaya masing-masing, membangun intuisi perasaan saling memahami satu sama lain dan tidak dibatasi menyalurkan ide-ide inspirasi untuk memecahkan masalah bersama antara TKA dan TK Pendamping selama kegiatan informal diluar kantor tersebut berlangsung. Kegiatan tersebut terbukti efektif memudahkan pertukaran informasi yang sejalan hingga tidak terjadi kesalahan penafsiran (error in interpretation) dan miscommunication karena berusaha saling memahami (Almaida \& Warsono, 2007). Hal tersebut sejalan dengan temuan penelitian sebelumnya bahwa Kerjasama yang bersahabat (Faraj \& Sproull, 2000) dan rasa saling percaya (Bosch-Sijtsema \& Postma, 2009) dapat membantu meningkatkan komunikasi dan pemahaman pengetahuan mereka, yang dapat memfasilitasi proses implementasi proyek dan meningkatkan keberhasilannya.

Kepercayaan mendorong berbagi pengetahuan diantara tim (Goh, 2002; Hasnain, 2012; Ko, 2010) dan kepercayaan adalah salah satu faktor kunci efektifnya keberhasilan transfer pengetahuan dan teknologi (Nahapiet \& Ghosal, 1998). Saling percaya membuat aktor merasa lebih percaya diri dan aman untuk saling terbuka (Wang, Ashleigh, \& Meyer, 2006). Di sisi lain, kurangnya kepercayaan adalah hambatan untuk transfer pengetahuan karena menghasilkan ketidakpastian dan risiko (Hislop, 2005) di antara semua aktor yang terkait dengan transfer pengetahuan. Kepercayaan adalah subjek interaksi dari waktu ke waktu (Dawson, 2000). Ketika kepercayaan meningkat di antara para pihak, keyakinan tentang kepastian pengecualian di masa depan akan berkembang (Wathne, Roos, \& von Krogh, 1996). Di sisi lain, kurangnya kepercayaan mengurangi kinerja organisasi (Debowski, 2006) dan menciptakan hambatan untuk transfer pengetahuan (Davenport \& Prusak, 2000). Beberapa perusahaan pengguna TKA di Yogyakarta sudah ada yang menerapkan metode ini dalam kegiatan pendampingan untuk alih pengetahuan dan teknologi. Perusahaan memfasilitasi kegiatan diskusi dengan TKA di luar kantor dengan menyediakan budget khusus dalam bentuk Employer Welfare (kesejahteraan karyawan) selama menjalankan aktivitas pendampingan. Metode seperti ini dapat dikategorikan sebagai off the job training.

\section{F. Proses Monitoring dan Evalusai Kegiatan Pendampingan}


Meskipun pemerintah sampai saat ini tidak melakukan monitoring dan evaluasi alih pengetahuan dan teknologi melalui kegiatan pendampingan TKA secara rutin dan berkelanjutan, beberapa perusahaan pengguna TKA tetap melakukan evaluasi dan monitoring kegiatan pendampingan TKA masing-masing pada periode waktu tertentu seperti minguan, triwulanan, dan tahunan. Rata-rata perusahaan melakukan proses pemantauan tersebut setiap 1 bulan, atau 6 bulan, atau 8 bulan sekali. Evaluasi dan monitoring dilakukan dengan membuat laporan pelaksanaan pendampingan TKA dari logbook harian atau dokumen berisi detil butirbutir target kegiatan pendampingan yang telah disepakati bersama-sama TKA dan TK Pendamping saat orientasi atau tahapan brainstorming awal sebelum pendampingan dilakukan. Selain itu, Perusahaan Pengguna TKA juga melakukan evaluasi dan monitoring kegiatan pendampingan TKA melalui alat bantu berupa formulir kuesioner hingga wawancara dan diskusi langsung dengan TKA dan TK Pendamping bersama-sama untuk memantau perkembangan alih keahlian dan teknologi secara berkala. Adapun butir kegiatan yang dievaluasi dan dimonitoring kepada masingmasing TKA dan TK Pendamping yaitu berkaitan dengan proses alih IPTEK, teknis pekerjaan, strategi pengembangan, sistem kerja, kualitas kerja, dan produktivitas kerja.

Hasil penelitian menunjukkan $71 \%$ menyatakan bahwa proses pendampingan belum dilakukan dengan baik oleh perusahaan pengguna TKA yang artinya alih keahlian dan teknologi belum terjadi dengan sukses. Sementara hanya $29 \%$ responden yang merasakan adanya alih keahlian dan teknologi dalam kegiatan pendampingan telah benar-benar baik dilakukan (yaitu pada sektor jasa pendidikan). Sementara itu, selain menambah pengetahuan dan keahlian, salah satu motivasi pendorong bagi TK Pendamping menerima tawaran perusahaan untuk mendampingi TKA selama bekerja adalah adanya kesempatan besar mendapatkan penghargaan atau insentif lain setelah kegiatan pendampingan selesai, seperti kenaikan gaji karena keahlian yang sudah meningkat, promosi pangkat atau jabatan pada tingkat yang mendekati hingga menggantikan jabatan TKA yang didampingi. Hal tersebut sejalan dengan temuan (Szulanski, 2000; Kalling, 2003; Stenmark, 2001) bahwa motivasi kedua belah pihak (unit sumber dan unit penerima) secara khusus berpengaruh pada alih pengetahuan serta peneliti lain berteori dan menemukan sebuah hubungan positif antara motivasi dan alih pengetahuan (Argote, 1999 dalam Ko, Kirsch, \& King, 2005). Namun pada praktiknya, mayoritas Perusahaan Pengguna TKA di Yogyakarta justru tidak memberikan penghargaan lain setelah TK Pendamping selesai menjalankan tugas pendampingan dengan baik.

Akibat yang terjadi adalah banyak TK Pendamping yang mengundurkan diri (resign) ditengah-tengah kegiatan pendampingan TKA. Beberapa hal diantaranya disebabkan oleh tingkat kesulitan, beban tugas dan tanggungjawab TK Pendamping yang diemban terlalu besar dengan kondisi tanpa disertai kompensasi tambahan yang diberikan Perusahaan atas penugasan pendampingan TKA tersebut. Selain itu, adanya tren "Pembajakan Karyawan" marak dilakukan oleh perusahaan pesaing dengan memberikan tawaran kerja yang jauh lebih menarik dibandingan tempat kerja mereka saat ini hingga menjadikan tingkat turnover TK Pendamping tinggi. Dinamika tersebut menjadi hambatan-hambatan alih pengetahuan dalam kegiatan pendampingan sehingga menjadi terputus dan tidak selesai (Sangkala, 2007). Langkah antisipasi dilakukan perusahaan pengguna TKA dengan menyediakan back up TK Pendamping yaitu mewajibkan sekitar 2-3 orang TK Pendamping pada setiap TKA yang bekerja.

\section{G. Tindakan Perbaikan Yang Perlu Dilakukan Pemerintah}

Tidak adanya pedoman baku pelaksanaan program kegiatan pendampingan TKA yang diterbitkan oleh pemerintah selaku regulator yang menaungi bidang tenaga kerja asing, menyebabkan banyak permasalahan Perusahaan Pengguna TKA menjalankan kewajiban kegiatan pendampingan mulai dari hanya sekedar memenuhi persyaratan administrasi saja dimana setelah RPTKA disahkan, proses pendampingan tidak benar-benar dilaksanakan oleh TK Pendamping dan TKA di perusahan dengan alasan sulitnya teknis pelaksanaan alih pengetahuan, keahlian dan teknologi di lapangan. Dan banyak diantara perusahan pengguna TKA juga mengalami kebingungan bagaimana mengukur hasil akhir dari kesuksesan alih pengetahuan, keahlian dan teknologi dalam kegiatan pendampingan TKA tersebut. Sehingga, adanya petunjuk teknis dan pelaksanaan kegiatan pendampingan baku dan 
terstandar dari pemerintah saat ini menjadi sangat diperlukan.

Petunjuk teknis dan pelaksanaan tersebut mengatur secara rinci butir-butir tahapan dan standar kegiatan yang dilakukan dalam kegiatan program pendampingan TKA mulai dari proses seleksi hingga proses monitoring dan evaluasi kegiatan. Kewajiban melaporkan perkembangan alih keahlian dan teknologi dalam kegiatan pendampingan TKA perlu disampaikan Perusahaan Pengguna TKA kepada Pemerintah secara berkala pada portal pelaporan online (daring) bersamaan dengan pengajuan atau perpanjangan RPTKA. Pelaporan program pendampingan disatukan dengan pelaporan pengajuan RPTKA tersebut ditujukan agar Perusahaan Pengguna TKA tidak terbebani masalah administrasi dengan tidak menyiapkan dokumen ulang terkait kegiatan pendampigan TKA diwaktu yang berbeda.

Monitoring dan evaluasi kegiatan pendampingan TKA secara khusus hingga saat ini belum dilakukan oleh pemerintah yang membidangi TKA di Yogyakarta. Pemerintah hanya memberikan penyuluhan mengenai tata cara penggunaan TKA melalui Disnaker Provinsi Yogyakarta yang kemudian ditindaklanjuti oleh Disnaker kota masingmasing dengan sekedar menanyakan bagaimana pendampingan TKA pada setiap perusahaan pengguna TKA saat perpanjangan RPTKA tanpa adanya pendalaman lebih. Oleh karena itu, sudah saatnya pemerintah melakukan monitoring dan evaluasi kegiatan pendampingan TKA secara menyeluruh yang wajib disampaikan oleh setiap Perusahaan Pengguna TKA secara periodik kepada pemerintah melalui Kementerian Ketenagakerjaan cq. Direktorat PTKA maupun Disnaker Provinsi dan Disnaker Kabupaten/Kota.

\section{KESIMPULAN DAN SARAN}

Penunjukan TK Pendamping pada Perusahaan Pengguna TKA di Yogayakarta menggunakan dua cara yaitu (1) menanyakan kesediaan calon TK Pendamping untuk menjadi tenaga kerja pendamping serta motivasi diri untuk berkembang, atau (2) dipilih langsung oleh pimpinan. Perusahaan pengguna TKA menetapkan persyaratan seleksi dan perekrutan TK Pendamping diantaranya berstatus karyawan tetap, memiliki kesesuaian bidang ilmu dengan TKA, memiliki karakter komunikatif dan aktif, pendidikan minimal D3 atau Sarjana, pernah atau sedang menjabat pekerjaan yang berhubungan erat dengan tugas jabatan TKA, memiliki kemampuan berbahasa inggris atau bahasa asing lainnya dengan baik sebagai kriteria utama, dan lain sebagainya.

Tidak adanya pedoman baku/teknis pelaksanaan kegiatan pendampingan TKA yang ditetapkan oleh pemerintah untuk setiap perusahaan pengguna TKA, mengakibatkan mayoritas Perusahaan pengguna TKA tidak memiliki SOP dasar kegiatan pendampingan dalam rangka alih keahlian dan teknologi. Pelaksanaan pendampingan rata-rata telah dimulai sejak TKA mulai bekerja hingga kurang dari 3 bulan pertama dalam rentang waktu pendampingan 7-12 bulan dan 1-10 jam per minggu. Mayoritas perusahaan Pengguna TKA di Yogayakarta menjadikan kegiatan pendampingan sebagai tugas tambahan bagi karyawan lama (TKI) yang ditunjuk sehingga tidak membebastugaskan mereka dari beban pekerjaan lainnya selama bertugas mendampingi TKA.

Efektivitas pendampingan TKA di Yogyakarta dilihat dari faktor komunikasi yaitu Interaksi aktif diantara TKA dan TK Pendamping selama kegiatan pendampingan memberikan kemudahan semua Informasi dan pesan penting dari TKA dapat dipahami dengan baik oleh TK Pendamping, baik menggunakan bahasa lisan atau tanpa berkomunikasi dengan menggunakan bahasa isyarat. Pada sisi keterampilan, TK Pendamping menjadi lebih teliti dalam menjalankan pekerjaan. Pada sisi pengetahuan, TKA sangat terbuka dan mudah berbagi pengetahuan kepada TK Pendamping. Pada sisi attitude, TKA yang didampingi memiliki etos kerja yang tinggi dan TK Pendamping tidak kesulitan mengikuti pola kerja TKA yang didampingi.

Metode ideal dalam pelaksanaan kegiatan pendampingan TKA di Yogyakarta dilakukan melalui kombinasi antara on the job training dan off the job training dengan komposisi 80:20. Proses alih pengetahuan dan teknologi melalui pendampingan akan memberikan hasil lebih baik jika lebih banyak diisi dengan on the job training melalui kegiatan bimbingan dan penyuluhan (coaching and counceling) serta instruksi terkait pekerjaan (job instruction). Selain itu, keberhasilan alih pengetahuan, keahlian dan teknologi dalam pendampingan juga ditemukan pada metode off the job training 
yang dilakukan melalui kegiatan-kegiatan informal yang dibangun di luar kantor antara TKA dan TK Pendamping, seperti bersepeda pagi bersama, naik gunung bersama, diskusi santai di café hingga sekedar mengadakan "Potluck". Perusahaan pengguna TKA di Yogyakarta memfasilitasi kegiatan tersebut dengan budget khusus berbentuk Employer Welfare (kesejahteraan karyawan) yang digunakan selama aktivitas pendampingan.

Pemerintah secara khusus belum melakukan monitoring dan evaluasi kegiatan pendampingan TKA atau sekedar memantau apakah alih pengetahuan dan teknologi telah berhasil dilakukan oleh perusahaan atau tidak. Meskipun demikian, beberapa perusahaan di Yogyakarta tetap melakukan monitoring dan evaluasi internal yang dilakukan dengan membuat logbook berisi materi kegiatan dan target yang harus dicapai dan ditinjau setiap periode waktu tertentu (bulanan) selama kegiatan pendampingan TKA berlangsung.

Hasil evaluasi kegiatan pendampingan TKA di Yogyakarta menunjukkan bahwa secara umum alih keahlian dan teknologi belum terjadi dengan baik, hanya pada sektor jasa pendidikan pendampingan TKA telah berjalan sukses. Pendampingan belum efektif dilakukan akibat TK Pendamping masih terikat oleh beban pekerjaan lainnya serta Perusahaan Pengguna TKA di Yogyakarta secara umum justru tidak memberikan penghargaan lain setelah TK Pendamping selesai menjalankan tugas pendampingannya dengan baik, sehingga banyak TK pendamping mengundurkan diri di tengah-tengah kegiatan pendampingan TKA.

Saran penelitian ini adalah sudah menjadi kebutuhan mendesak bagi perusahaan pengguna TKA saat ini untuk memperoleh sebuah panduan teknis dan pelaksanaan kegiatan pendampingan TKA dari Pemerintah sebagai bentuk tindaklanjut lebih konkrit dari peraturan hukum yang sudah ada. Selain itu, pemerintah melalui instansi yang membidangi TKA sebaiknya melakukan pemantauan rutin dengan wajib lapor melalui daring TKA online bersamaan dengan pelaporan TKA biasanya agar perusahaan dapat sekaligus menyiapkan dan melampirkan dokumen yang diperlukan, tanpa memberikan beban kerja tambahan.

\section{DAFTAR PUSTAKA}

Almaida, A., \& Warsono, S. (2007, Juli 26-28). Mekanisme Alih Pengetahuan Anggota Tim Manajemen Atas dan Eksekutif STI: Menuju Keselarasan Sistem Informasi Strategik. Simposium Nasional Akuntansi $X$.

Argote, L. (1999). Organizational Learning: Creating, Retaining and Transferring Knowledge. Boston: Kluwer.

Bosch-Sijtsema, P., \& Postma, T. (2009). Cooperative Innovation Projects: Capabilities and. Journal of Product Innovation Management, 58-70.

Davenport, T., \& Prusak, L. (2000). Working Knowledge: How Organizations Manage What They Know. MA: Harvard Business School Press.

Dawson, R. (2000). Developing KnowledgeBased Client Relationships: The Future of Professional Services. MA: ButterworthHeinemann.

Debowski, S. (2006). Knowledge Management. Sydney: John Wiley \& Sons Australia Ltd.

Faraj, S., \& Sproull, L. (2000). Coordinating Expertise in Software Development Teams. In Management Science (pp. 1554-1568).

Goh, S. (2002). Managing effective knowledge transfer: An integrative framework. Journal of Knowledge Management Vol. 6, 23-30.

Hasnain, S. (2012). The Impact of Trust on Knowledge Transfer: An Empirical Study in the NGOs in Bangladesh. UK: Aberystwyth University Wales.

Hislop, D. (2005). Knowledge Management in Organizations-A Critical Introduction. NY: Oxford University Press.

Kalling, T. (2003). Organization-internal transfer of knowledge and the role of motivation: A qualitative case study. Knowledge and Process Management, Vol. 10 No. 2, 115-126.

Ko, D. (2010). Consultant competence trust doesn't pay off but benevolence trust does! Managing knowledge with care. Journal of Knowledge Management, Vol. 14, No. 2, 202-213.

Ko, D., Kirsch, L., \& King, W. (2005). Antecedents of Knowledge Transfer from Consultations to Clients. MIS Quarterly, 59-86.

Lahti, R., \& Beyerlein, M. (2000). Knowledge Transfer and Management Consulting: A 
Look at "The Firm". Business Horizons, 65-73.

Mariana, Y. B., Suharno, \& Hidayah, N. (2017). Perlindungan Hukum Terhadap Penggunaan Tenaga Kerja Asing Pada PT Lingua Munda Surakarta. Seminar Nasional dan Call for Paper UNIBA 2017 "Perlindungan hukum terhadap tenaga kesehatan dan pasien dalam perspektif uu 36 tahun 2014". Surakarta: Universitas Islam Batik Surakarta.

Nahapiet, J., \& Ghosal, S. (1998). Social capital, intellectual capital, and the organizational advantage. The Academy of Management Review, Vol. 2 No.23, 242-266.

Nonaka, I. (1994). A dynamic theory of organizational knowledge creation. Organization Science, 14-37.

Republik Indonesia. (2003). Undang-Undang RI No. 13 Tahun 2003 Tentang Ketenagakerjaan. In Lembar RI No.39 Tahun 2003. Jakarta: Sekretariat Negara.

Republik Indonesia. (2007). Undang-Undang No.25 Tahun 2007 Tentang Penanaman Modal. In Lembar Negara RI Tahun 2007 No.67. Jakarta: Sekretariat Negara.

Republik Indonesia. (2012). Keputusan Menteri Tenaga Kerja dan Transmigrasi RI No.40 Tahun 2012 Tentang Jabatan-Jabatan Yang Dilarang Diduduki Tenaga Kerja Asing. Jakarta: Kementerian Tenaga Kerja Dan Transmigrasi.

Republik Indonesia. (2018). Peraturan Menteri Ketenagakerjaan RI No.10 Tahun 2018 Tentang Tata Cara Penggunaan Tenaga Kerja Asing. Jakarta: Kementerian Ketenagakerjaan.

Republik Indonesia. (2018). Peraturan Presiden RI No.20 Tahun 2018 Tentang Penggunaan Tenaga Kerja Asing. In Lembar Negara RI Tahun 2018 No.39. Jakarta: Sekretariat Kabinet RI.

Republik Indonesia. (2019). Keputusan Menteri Ketenagakerjaan RI No.228 Tahun 2019. Jakarta: Kementerian Ketengakerjaan.
Sangkala. (2007). Knowledge Management: Suatu Pengantar Memahami Bagaimana Organisasi Mengelola Pengetahuan Sehingga Menjadi Organisasi Yang Unggul. Jakarta: PT Rajagrafindo Persada.

Stenmark, D. (2001). Leveraging tacit Organizational knowledge. Journal of Management Information Systems, Vol.17 No.3, 9-24.

Szulanski, G. (1996). Exploring Internal Stickiness: Impediments to the Transfer of Best Practice within the Firm. Strategic Management Journal, 27-43.

Thomas, T., \& Prétat, C. (2009). The Process of Knowledge Transfer. Swedia: Baltic Business School, Universitas Kalmar.

Tim Perbankan, \& Enquiry Point. (2007). Tenaga Kerja Asing Pada Perbankan Nasional. In Buletin Hukum Perbankan Dan Kebanksentralan (pp. Volume 5, Nomor 3,). Jakarta.

Tim Publikasi Katadata. (2019, Agustus 04). Investasi dan Tenaga Kerja. Retrieved from Katadata: https://katadata.co.id/berita/2019/04/08/inv estasi-dan-tenaga-kerja

Wang, J., Ashleigh, M., \& Meyer, E. (2006). Knowledge sharing and team Trustworthiness: it"s all about social ties. Knowledge Management Research \& Practice, Vol.4, 175-186.

Wathne, K., Roos, J., \& von Krogh, G. (1996). Towards a theory of knowledge transfer in a cooperative context". In von Krogh, $G$. and Roos,J.eds. Managing Knowledge: Perspectives on Cooperation and Competition. London: SAGE Publications Ltd.

Yudanto, N., Prasetyo, A. J., Nugroho, F., \& Sadha, P. U. (2010). Laporan Survey Nasional Tenaga Kerja Asing di Indonesia Tahun 2009. Jakarta: Biro Statistik Ekonomi Moneter Bank Indonesia. 